Volume 16, No. 2, Juli 2019

\title{
PENGGUNAAN KUNYIT PUTIH (Curcuma zedoaria) UNTUK PENGENDALIAN LARVA Aedes sp
}

\author{
Ahliana, Isnawati, Muhammad Irfa'i \\ Poltekkes Kemenkes Banjarmasin Jurusan kesehatan Lingkungan \\ Jl. H. Mistar Cokrokusumo No.1A Banjarbaru Kalimantan Selatan 70714 \\ E-mail: liaahliana12@gmail.com
}

\begin{abstract}
White Turmeric Larvicides (Curcuma zedoaria) Against Death of Aedes sp. Larvae. Dengue Hemorrhagic Fever is a disease transmitted through mosquito bites from the genus Aedes sp. Chemical control is carried out by killing larvae using abate but can cause resistance from the target organism, to solve this problem by using natural insecticides, namely white turmeric. This study aims to determine the effectiveness of white turmeric larvae (Curcuma zedoaria) on the death of Aedes sp. Larvae. The type of research used is pure experiment. In this study researchers can control the course of the experiment. The sample used was 25 larvae which were put into container boxes with various concentrations and length of contact time. The results of the analysis of concentration variations showed sig $<\alpha(0.247>0.05)$. The duration of contact showed sig $<\alpha(0.004$ $<0.05)$. The concentration variation has no effect while the contact time has an influence on the mortality of Aedes sp. Larvae. The LC50 value at 72 hours contact time is $0.25 \%$ and TU 400 value. The effectiveness of white turmeric larvacide is at a concentration of $0.6 \%$ which can kill 88\% of target insects / animals. Suggestion, to reduce the aroma of white turmeric as larvacide. Need to test other mosquito larvae. At the contact time of 48 hours with a concentration of $0.6 \% \pm 1$ teaspoon the juice of white turmeric rhizome in 1 liter of water was said to be effective.
\end{abstract}

Keywords : Dengue Hemorrhagic Fever; Larvae Aedes sp; Larvasida White Turmeric

\begin{abstract}
Abstrak: Penggunaan Kunyit Putih (Curcuma zedoaria) Untuk Pengendalian Larva Aedes sp. Demam Berdarah Dengue adalah penyakit yang ditularkan melalui gigitan nyamuk dari genus Aedes sp. Pengendalian secara kimiawi dilakukan dengan membunuh larva menggunakan abate tetapi dapat menimbulkan resistensi dari organisme target, untuk memecahkan masalah tersebut dengan penggunaan insektisida alami, yaitu kunyit putih. Penelitian ini bertujuan untuk mengetahui efektivitas larvasida kunyit putih (Curcuma zedoaria) terhadap kematian larva Aedes sp. Jenis penelitian yang digunakan adalah eksperimen murni. Pada penelitian ini peneliti dapat mengontrol jalannya eksperimen. Sampel yang digunakan adalah 25 larva yang dimasukkan ke dalam box container dengan berbagai variasi konsentrasi dan lama waktu kontak. Hasil analisis variasi konsentrasi menunjukkan sig< $\alpha(0,247>0,05)$. Lama waktu kontak menunjukkan sig< $\alpha(0,004<0,05)$. Variasi konsentrasi tidak memiliki pengaruh sedangkan lama waktu kontak memiliki pengaruh terhadap kematian larva Aedes sp. Nilai $L C_{50}$ pada lama waktu kontak 72 jam adalah 0,25\% dan nilai TU 400. Efektivitas larvasida kunyit putih berada pada konsentrasi 0,6\% yang dapat membunuh $88 \%$ serangga/hewan sasaran. Saran, untuk mengurangi aroma dari kunyit putih sebagai larvasida. Perlu melakukan uji coba terhadap larva nyamuk lainnya. Pada waktu kontak 48 jam dengan konsentrasi $0,6 \% \pm 1$ sendok teh air perasan rimpang kunyit putih dalam 1 liter air telah dikatakan efektif.
\end{abstract}

Kata kunci : Demam Berdarah Dengue; Larva Aedes sp; Larvasida Kunyit Putih

\section{PENDAHULUAN}

Data dari seluruh dunia menunjukkan Asia menempati urutan pertama dalam jumlah penderita Demam Berdarah Dengue setiap tahunnya. Sementara itu, terhitung sejak tahun 1968 hingga tahun 2009, World Health Organization (WHO) mencatat negara Indonesia sebagai negara dengan kasus Demam Berdarah Dengue tertinggi di Asia Tenggara. Di Indonesia kasus Demam 
Berdarah Dengue pertama kali ditemukan di kota Surabaya pada tahun 1968, dimana sebanyak 58 orang terinfeksi dan 24 orang diantaranya meninggal dunia[1].

Penyakit Demam Berdarah Dengue adalah penyakit yang disebabkan oleh virus Dengue, yang tergolong ArthropodBorne Virus, genus Flavivirus, dan famili Flaviviridae ditularkan melalui gigitan nyamuk dari genus Aedes, terutama Aedes aegypti atau Aedes albopictus. Penyakit Demam Berdarah Dengue dapat muncul sepanjang tahun dan dapat menyerang seluruh kelompok umur. Penyakit ini berkaitan dengan kondisi lingkungan dan perilaku masyarakat[2].

Di Indonesia pada tahun 2017 dengan jumlah penduduk 261.890.872 jiwa terdapat jumlah kasus Demam Berdarah Dengue sebanyak 59.047 (22,55per 100.000 penduduk) kasus dengan jumlah kematian sebanyak 444 orang $(0,75 \%)$. Di Kalimantan Selatan dengan jumlah penduduk 4.119.794 jiwa terdapat jumlah kasus Demam Berdarah Dengue sebanyak $544(13,20$ per 100.000 penduduk) kasus dengan jumlah kematian sebanyak 2 orang (0,37\%). Di Kalimantan Selatan terdapat 13 Kabupaten/Kota dengan jumlah yang terjangkit yaitu sebesar 12 (92,31\%) Kabupaten/Kota[3].

Pengendalian yang paling sering dilakukan saat ini adalah pengendalian secara kimiawi, karena dianggap bekerja lebih efektif dan hasilnya cepat telihat dibandingkan pengendalian secara biologis pengendalian yang dilakukan dengan membunuh larva dari vektor untuk memutus rantai penularannya dengan menggunakan abate (temephos). Bahan insektisida tersebut walaupun memiliki efektivitas yang tinggi, akan tetapi bisa berdampak negatif terhadap lingkungan dan menimbulkan resistensi dari organisme target [4]. Salah satu cara untuk memecahkan masalah tersebut adalah dengan penggunaan insektisida alami yang lebih ramah lingkungan atau dengan tumbuhan hayati[5].

Indonesia terkenal kaya akan keanekaragaman hayati, termasuk jenis tumbuhan yang mengandung bahan aktif larvasida[5]. Salah satu tumbuhan yang diduga berfungsi sebagai larvasida nabati yaitu rimpang kunyit putih (Curcuma zedoaria). Rimpang kunyit putih mengandung senyawa bioaktif berupa minyak atsiri, Minyak atsiri dapat berpotensi sebagai insektisida karena diketahui bersifat toksik pada rentang $\mathrm{pH}$ yang lebar, stabil terhadap cahaya dan panas, dan tidak membentuk lapisan yang permanen pada permukaan air untuk waktu yang lama[6].

Mekanisme kerja senyawa tersebut yaitu menyebabkan gangguan pada sistem pengiriman sinyal perangsang makan melalui penghambatan reseptor - reseptor perasa pada larva. Hal ini menyebabkan aktivitas makan yang rendah pada larva, sehingga mengakibatkan asupan energi yang digunakan untuk perkembangan larva menjadi berkurang dan proses pertumbuhan menjadi terhambat[7].

Senyawa lainnya yang terkandung dalam rimpang kunyit putih yaitu senyawa flavonoid yang bekerja sebagai racun pernafasan pada larva. Senyawa tersebut menimbulkan kelayuan saraf dan kerusakan siphon pada larva, sehingga mengakibatkan larva tidak dapat bernafas [7]. Penelitian sebelumnya, daya bunuh air perasan rimpang kunyit terhadap kematian larva Aedes aegypty diperoleh hasil jumlah kematian larva Aedes aegypty pada konsentrasi $0,5 \%$ sebesar $16 \%$, pada konsentrasi $1 \%$ sebesar $38 \%$, pada konsentrasi $1,5 \%$ sebesar $63 \%$, dan pada konsentrasi $2 \%$ sebesar $80 \%$ dengan nilai $\mathrm{LC}_{50}$ sebesar $1,144 \%$ dan $\mathrm{LC}_{90}$ sebesar $3,018 \%$ [7] dengan memiliki kandungan larvasida nabati yaitu minyak atsiri. Penelitian lain mengatakan minyak atsiri rimpang kunyit putih (Curcuma zedoaria) sebagai larvasida dalam membunuh larva nyamuk Aedes aegypti instar IV awal. Besar konsentrasi minyak atsiri rimpang kunyit putih (Curcuma zedoaria) yang efektif membunuh $50 \%$ populasi larva uji $\left(\mathrm{LC}_{50}\right)$ adalah 54,5 ppm[6]. Penulis tertarik melakukan penelitian tentang efektivitas rimpang kunyit putih (Curcuma zedoaria) terhadap kematian larva Aedes sp dalam bentuk air perasan rimpang kunyit putih. 


\section{BAHAN DAN CARA PENELITIAN}

Bahan yang digunakan yaitu air perasan rimpang kunyit putih dan larva Aedes sp instar III dengan alat penelitian adalah breaker glass, pipet tetes, pipet ukur, nampan, pisau, alat pemarut, saringan, box container dan gelas ukur.

Penelitian yang digunakan adalah true eksperimen (eksperimen murni) yaitu eksperimen yang sebenarnya, karena dalam jenis penelitian ini peneliti dapat mengontrol jalannya eksperimen, dengan ciri kelompok kontrol dan sampel dipilih secara random (acak) dengan desain rancangan e-sederhana (post-test only control group design) yaitu adanya intervensi atau perlakuan dari peneliti, dengan memberikan 5 perlakuan konsentrasi $0,2 \%, 0,4 \%, 0,6 \%, 0,8 \%, 1 \%$ dan kontrol serta varisi lama waktu kontak 24 jam, 48 jam dan 72 jam pada setiap konsetrasi. Masing-masing perlakuan dilakukan replikasi sebanyak 4 kali.

Siapkan $1 \mathrm{~kg}$ rimpang kunyit putih yang telah dikupas dan dibersihkan dengan air mengalir agar terhindar dari kotoran yang masih menempel selanjutnya siapkan nampan untuk tempat rimpang kunyit putih, parut larvasida nabati kunyit putih tersebut dan saring untuk memisahkan hasil perasan rimpang kunyit putih dengan ampasnya lalu masukkan air perasan larvasida nabati dengan variasi konsentrasi yang telah direntangkan ke dalam masing-masing box container yang berisi air sebanyak 1 liter selanjutnya aduk masing-masing box container agar tercampur rata, masukkan masing-masing 25 larva Aedes sp kedalam box container yang berisi larvasida nabati kunyit putih dan terakhir lihat jumlah kematian larva setiap 24 jam selama 3 hari, catat kematian larva dan masukkan ke dalam tabel uji efektivitas.

Analisis data yang digunakan pada penelitian ini adalah uji analisis one way anova. Analisi ini bertujuan untuk mengetahui pengaruh konsentrasi kunyit putih terhadap kematian larva Aedes $s p$ dan lama waktu kontak kunyit putih (Curcuma zedoaria) sebagai larvasida nabati terhadap kematian larva Aedes $s p$ dan analisis Probit digunakan untuk mengetahui dan menentukan Lethal Consentration $50 \quad\left(\mathrm{LC}_{50}\right)$ efektivitas larvasida nabati rimpang kunyit putih (Curcuma zedoaria) terhadap kematian larva Aedes sp.

\section{HASIL DAN PEMBAHASAN}

Sebelumnya dilakukan uji pendahuluan untuk merperoleh $\mathrm{LC}_{50}$ larvasida kunyit putih dengan konsentrasi $0 \%, 0,4 \%, 0,8 \%, 1,2 \%, 1,6 \%$ dan $2 \%$ Berdasakan analisis probit menggunakan aplikasi minitab 18, diperoleh $\mathrm{LC}_{50}$ kunyit putih adalah $0,40 \%$ dengan batas atas $0,48 \%$ dan batas bawah $0,32 \%$ sedangkan $\mathrm{LC}_{99}$ adalah 0,84\% dengan batas atas $1,10 \%$ dan batas bawah $0,71 \%$ tahap selanjutnya adalah melakukan uji toksisitas dengan hasil dari uji pendahuluan, yaitu dengan variasi konsentrasi $0 \%, 0,2 \%, 0,4 \%, 0,6 \%, 0,8 \%$ dan $1 \%$.

Dilakukan uji penelitian dengan konsentrasi yaitu $0 \%, 0,2 \%, 0,4 \%, 0,6 \%$, $0,8 \%$ dan $1 \%$ dengan waktu pengamatan 24 jam, 48 jam dan 72 jam, penggunaan waktu pengamatan 24 jam, 48 jam dan 72 jam tersebut karena efek yang timbul tidak hanya bergantung pada frekuensi pemberian dengan dosis berbeda saja tetapi mungkin juga bergantung pada durasi paparannya. dikatakan toksisitas cepat merupakan manifestasi yang segera timbul setelah pemberian bahan. Sedangkan toksisitas lambat merupakan manifestasi yang timbul akibat bahan selang beberapa waktu dari waktu pemberian [8], untuk mengetahui apakah larvasida kunyit putih (Curcuma zedoaria) memiliki toksisitas yang cepat atau lambat terhadap kematian larva Aedes sp maka diperoleh hasil yang dapat di lihat pada Tabel 1 berikut : 
Tabel 1 Uji Toksisitas Larvasida Kunyit Putih (Curcuma zedoaria) Terhadap Kematian Larva Aedes $s p$

\begin{tabular}{|c|c|c|c|c|c|c|c|c|}
\hline \multirow[t]{2}{*}{$\begin{array}{l}\text { Konsentrasi \% } \\
\text { (persen) }\end{array}$} & \multirow[t]{2}{*}{ Replikasi } & \multirow[t]{2}{*}{$\begin{array}{c}\text { Jumlah Larva } \\
\text { yang Diujikan } \\
\text { (ekor) }\end{array}$} & \multicolumn{3}{|c|}{$\begin{array}{c}\text { Jumlah larva yang } \\
\text { mati }\end{array}$} & \multirow[t]{2}{*}{ Suhu } & \multirow[t]{2}{*}{$\mathrm{pH}$} & \multirow[t]{2}{*}{$\begin{array}{c}\text { Total } \\
\text { (Ekor larva }\end{array}$} \\
\hline & & & 24 & 48 & 72 & & & \\
\hline \multirow[t]{4}{*}{$0 \%$} & R1 & 25 & 0 & 0 & 0 & \multirow{4}{*}{28} & \multirow{4}{*}{6} & 0 \\
\hline & $\mathrm{R} 2$ & 25 & 0 & 0 & 0 & & & 0 \\
\hline & R3 & 25 & 0 & 0 & 0 & & & 0 \\
\hline & $\mathrm{R} 4$ & 25 & 0 & 0 & 0 & & & 0 \\
\hline \multirow[t]{4}{*}{$0,2 \%$} & $\mathrm{R} 1$ & 25 & 6 & 15 & 16 & \multirow{4}{*}{29} & \multirow{4}{*}{6} & 16 \\
\hline & $\mathrm{R} 2$ & 25 & 6 & 15 & 16 & & & 16 \\
\hline & R3 & 25 & 6 & 15 & 17 & & & 17 \\
\hline & R4 & 25 & 5 & 15 & 16 & & & 16 \\
\hline \multirow[t]{4}{*}{$0,4 \%$} & $\mathrm{R} 1$ & 25 & 8 & 17 & 18 & \multirow{4}{*}{29} & \multirow{4}{*}{6} & 18 \\
\hline & R2 & 25 & 9 & 18 & 19 & & & 19 \\
\hline & R3 & 25 & 8 & 17 & 19 & & & 19 \\
\hline & R4 & 25 & 8 & 17 & 19 & & & 19 \\
\hline \multirow[t]{4}{*}{$0,6 \%$} & $\mathrm{R} 1$ & 25 & 10 & 20 & 23 & \multirow{4}{*}{29} & \multirow{4}{*}{6} & 23 \\
\hline & $\mathrm{R} 2$ & 25 & 11 & 20 & 22 & & & 22 \\
\hline & R3 & 25 & 11 & 20 & 22 & & & 22 \\
\hline & $\mathrm{R} 4$ & 25 & 11 & 21 & 22 & & & 22 \\
\hline \multirow[t]{4}{*}{$0,8 \%$} & $\mathrm{R} 1$ & 25 & 14 & 23 & 24 & \multirow{4}{*}{29} & \multirow{4}{*}{6} & 24 \\
\hline & $\mathrm{R} 2$ & 25 & 14 & 22 & 23 & & & 23 \\
\hline & R3 & 25 & 14 & 21 & 23 & & & 23 \\
\hline & $\mathrm{R} 4$ & 25 & 13 & 21 & 23 & & & 23 \\
\hline \multirow[t]{4}{*}{$1 \%$} & $\mathrm{R} 1$ & 25 & 17 & 24 & 25 & \multirow{4}{*}{29} & \multirow{4}{*}{6} & 25 \\
\hline & R2 & 25 & 18 & 24 & 25 & & & 25 \\
\hline & R3 & 25 & 18 & 23 & 25 & & & 25 \\
\hline & $\mathrm{R} 4$ & 25 & 17 & 23 & 25 & & & 25 \\
\hline
\end{tabular}

Sumber : Ahliana, 2019

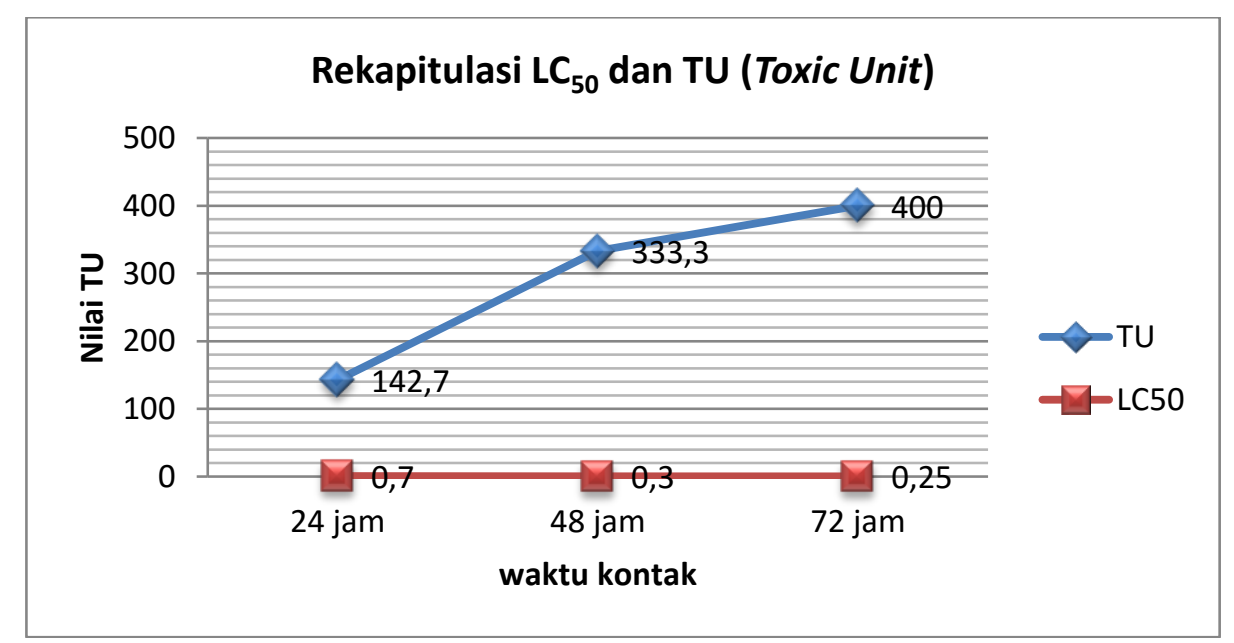

Gambar 1. Rekapitulasi LC ${ }_{50}$ dan TU (Toxic Unit) 
Hasil uji statistik menunjukkan $\operatorname{sig}<\alpha \quad(0,247>0,05)$ artinya tidak ada pengaruh variasi konsentrasi larvasida kunyit putih terhadap kematian larva Aedes sp sedangkan hasil uji statistik menunjukkan sig $<\alpha \quad(0,004<0,05)$ yang artinya ada pengaruh lama waktu kontak larvasida kunyit putih terhadap kematian larva Aedes sp, maka dilakukan uji lanjutan pada lama waktu kontak untuk melihat signifikansi perbedaan (perbedaan nyata) antar perlakuan terhadap nilai rata-rata masing-masing kematian larva Aedes sp dilakukan uji multiple comparison menggunakan LSD (Least Significant Difference). Hasil uji LSD menyatakan waktu kontak 24 jam $\neq 48$ jam yang artinya pada waktu kontak tersebut terlihat perbedaan yang nyata, waktu kontak 48 jam $=72$ jam, yang artinya pada waktu kontak tersebut tidak terlihat perbedaan yang nyata dan pada waktu kontak 24 jam $\neq 72$ jam yang artinya pada waktu kontak tersebut terlihat perbedaan yang nyata.

Semakin besar konsentrasi yang digunakan maka semakin banyak larva yang mati dan diketahui bahwa air perasan rimpang kunyit putih (Curcuma zeoaria) tidak mempunyai pengaruh terhadap kematian larva Aedes sp. Hasil analisis menunjukkan bahwa antara kelompok konsentrasi tidak mempunyai efek larvasida yang berbeda selama waktu kontak 3x24 jam. Penelitian sebelumnya [6] mengatakan bahwa minyak atsiri rimpang kunyit putih (Curcuma zedoaria) efektif sebagai larvasida dalam membunuh larva nyamuk Aedes sp dan menunjukkan bahwa ada perbedaan jumlah kematian larva dengan $(\mathrm{p}=0.000)$. penelitian ini membuktikan bahwa aktivitas larvasida dalam bentuk ekstrak minyak atsiri lebih efektif dibandingkan dengan dalam bentuk air perasan. Besarnya konsentrasi dan lama paparan air perasan rimpang kunyit sangat berpengaruh terhadap jumlah kematian larva Aedes sp. Semakin lama waktu paparan perlakuan, maka semakin besar jumlah kematian larva Aedes $s p$. Sehingga dari hasil tersebut dapat menunjukkan bahwa larvasida dari air perasan rimpang kunyit putih dapat mematikan larva seiring berjalannya waktu.

Nilai LC $_{50}$ tertinggi pada waktu kontak 24 jam dengan nilai $0,70 \%$ didapatkan nilai TU yang rendah dengan nilai 142,7 dan $\mathrm{LC}_{50}$ terendah pada waktu kontak 72 jam dengan nilai $0,25 \%$ didapatkan nilai TU yang tinggi dengan nilai 400 dengan konsentrasi larvasida $0,6 \%$ telah dikatakan efektif. Nilai TU (Toxic Unit) pada waktu kontak 72 jam yaitu sebesar 400 artinya intensitas racun yang terkandung di dalam air perasan rimpang kunyit putih sebesar 400 untuk mematikan satuan hewan uji. $\mathrm{LC}_{50}$ (Lethal Concentration 50) dan TU (Toxic Unit) yang efektif adalah $0,25 \%$ didapatkan nilai TU yang tinggi dengan nilai 400 , semakin kecil nilai $\mathrm{LC}_{50}$ semakin besar nilai TU (Toxic Unit) serta efektivitas larvasida kunyit putih berada pada konsentrasi $0,6 \%$.

\section{KESIMPULAN DAN SARAN}

Ada pengaruh lama waktu kontak larvasida kunyit putih, Nilai $\mathrm{LC}_{50}$ (Lethal Concentration 50) pada lama waktu kontak 72 jam adalah $0,25 \%$ dan nilai TU (Toxic Unit) yaitu 400 dan efektivitas larvasida kunyit putih berada pada konsentrasi $0,6 \%$. Perlu dilakukan penelitian untuk mengurangi aroma dari kunyit putih tersebut sebagai larvasida dengan melakukan pengolahan ekstrak kunyit putih.

\section{KEPUSTAKAAN}

1. Meilson H. E. Sallata, Erniwati Ibrahim MS. Hubungan Karakteristik Lingkungan Fisik dan Kimia dengan Keberadaan Larva Aedes aegypti di Wilayah Endemis DBD Kota Makassar. 2014.

2. Kemenkes. Profil Kesehatan Indonesia. 2016.

3. Kemenkes. Profil Kesehatan Indonesia 2017. 2017.

4. Nugroho AD. Kematian Larva Aedes aegypti Setelah Pemberian Abate Dibandingkan Dengan Pemberian Serbuk Serai. J Kesehat Masy 2013;7(1):91-6.

5. Permadi IGWDS. Keanekaragaman 
Tanaman Obat sebagai Larvasida dalam Upaya Pengendalian Vektor Demam Berdarah Dengue ( DBD ). sains dan Teknol Lingkung 2013; Vol 5:12-6.

6. Sembiring WSR. Efektivitas minyak atsiri rimpang kunyit putih Curcuma zedoaria sebagai larvasida terhadap nyamuk Aedes aegypti. J Buski
2012;Vol. 4(No. 2):pages 80-86.

7. Pratiwi AM. Daya Bunuh Air Perasan Rimpang Kunyit ( Curcuma domestica Val ) Terhadap Kematian Larva Aedes aegypti. 2016.

8. Mukono HJ. Toksikologi Lingkungan. Surabaya: AirLangga University Press; 2010. 